\title{
Effect of Locus of Control and Job Satisfaction on Employee Performance through Organizational Citizenship Behavior (OCB) on Accounting Department Personnel of Naval Base V Surabaya
}

\author{
Dyna Tistianingtyas and Parwoto
}

\section{ABSTRACT}

\begin{abstract}
This study aims to determine the effect of Locus of Control and Job Satisfaction on Organizational Citizenship Behavior (OCB) and Employee Performance and to determine the effect of $O C B$ as an intervening variable on Employee Performance on personnel of Lantamal V Surabaya (Naval Base V Surabaya) Accounting Department. This research model uses a type of causal research with quantitative methods. The sampling technique taken was saturated sampling technique. The data source used in this research is primary data in the form of a questionnaire. The data analysis technique used in this study was Partial Least Square. Factors that support research activities, namely the accounting staff of Lantamal V Surabaya totaling fifty people consisting of the military ranks Tamtama (Enlisted Officer), Bintara (Non Commisioned Officer), Perwira (Officer) and PNS AL (Civil Service Employee of Naval Force). Evaluation of the Organizational Citizenship Behavior (OCB) behavior in the staff of the Lantamal V Surabaya Accounting staff is very important because this behavior is the absolute responsibility of a Navy soldier in each work unit wherever they serve. In addition, an important thing for a staff in carrying out their work is the existence of Job Satisfaction. The importance of having human resources with good and optimal performance is expected by the staff of the Lantamal V Surabaya Accounting department. This cannot be separated from the perspective of the staff members of the Lantamal V Surabaya Accounting department in controlling the perceptions that each individual has to see the events that occur in his life both internally and externally. The results showed that: (1) Locus of Control has no significant effect on Organizational Citizenship Behavior (OCB); (2) Job satisfaction affects Organizational Citizenship Behavior (OCB); (3) Locus of Control and Job satisfaction affect Employee Performance; (4) Organizational Citizenship Behavior (OCB) has no effect on Employee Performance; (5) Locus of Control and Job satisfaction do not have a significant effect on Employee Performance through Organizational Citizenship Behavior (OCB).
\end{abstract}

Keywords: Locus of Control, Job satisfaction, Organizational Citizenship Behavior, Employee Performance.

\section{INTRODUCTION}

Today's dynamic work world, where tasks are increasingly being done in teams and requiring flexibility, organizations need employees who have Organizational Citizenship Behavior (OCB), such as helping other individuals on the team, volunteering to do extra work, avoiding conflicts with colleagues' work, obey regulations, and tolerate occasional work load and interruption [1]. The emergence of OCB has a positive impact not only for the members themselves but also contributes to the organization more than what the organization requires formally. Successful organizations have members who go beyond formal job responsibilities and are free to give their time and energy to succeed in the assigned job. Such behavior is not determined but contributes
Submitted : February 14, 2021

Published : March 9, 2021

ISSN: 2507-1076

DOI: $10.24018 /$ ejbmr.2021.6.2.752

Dyna Tistianingtyas

Magister Management, Mercu Buana University, Jakarta, Indonesia.

(e-mail: dyna.tistia@gmail.com) Parwoto

Magister Management, Mercu Buana University, Jakarta, Indonesia. (e-mail: pakwoto19@gmail.com)

*Corresponding Author

to the smooth functioning of the organization. Likewise, OCB behavior in the environment of staff personnel, the Lantamal V Surabaya account is very important because this behavior is a dominant part of the implementation of the line of command system which is the absolute responsibility of a Navy soldier in each work unit wherever they serve.

In addition, an important thing for an employee in carrying out his job is job satisfaction, where an employee will maintain high work performance if he gets job satisfaction from his job, and conversely an employee will sooner or later commit absenteeism, is unreliable and perform poorly if they do not get satisfaction in their work. That employees can become an important company asset if the work environment established by management satisfies employees so that it supports their work performance and employees will stay in 
the company [2]. The foregoing also occurs in the Lantamal V Surabaya Accounting department's work environment. In working and carrying out daily tasks at the office, Job satisfaction is also important. Therefore, in addition to salary income and food allowance, all personnel also receive several allowances to increase Job satisfaction, among others, allowances in the form of housing / mess facilities, health facilities, meeting the needs of work service uniforms and the most significant is performance allowances.

Employee performance is influenced by environmental factors, in addition to being influenced by individual attributes or traits in the form of skills, abilities, and so on which are followed by motivation or willingness, and opportunities given to employees [3]. Likewise, the performance of the Lantamal $\mathrm{V}$ Surabaya Accounting personnel is expected to be able to realize high loyalty and performance under the leadership of the Head of Lantamal V Surabaya Accounting department as the leader of the work unit, especially the work unit has an important role and authority in the fields of budget and finance throughout the Lantamal V Surabaya which include some Lanal (Naval Sub Base): Lanal Malang, Lanal Cilacap, Lanal Semarang, Lanal Yogyakarta, Lanal Tegal, Lanal Batuporon, Lanal Tegal, Lanal Banyuwangi, and Lanal Denpasar. Good performance criteria require employees to behave according to company expectations, but the company must also pay attention to aspects - aspects that can make employees survive and comfortable with the conditions and work environment.

Companies that realize the importance of maintaining employee performance will always pay attention to factors that can increase employee morale. Basically, employee performance is influenced by certain conditions, namely conditions that come from within the individual called individual factors and conditions that come from outside the individual are called situational factors [4]. One of the individual factors is locus of control. Every individual has beliefs and perceptions of everything that affects him. This belief is called locus of control. Some people think that effort and ability are factors that influence a person to achieve success, but some other people also have a mindset that factors from outside their control can lead them to success, including factors of luck, opportunity, fate, and destiny. This also happens to the staff of the Lantamal V Surabaya accounting department, with inherent strata (officers, noncommissioned officers, enlisted officers and civil service employee) as well as the level of education they have, greatly influences the thought that in achieving success must be accompanied by increasing abilities, skills and loyalty in carry out their work, but there are still personnel who think that way and make the morale and performance of the personnel decrease and tend to only carry out routine tasks without the desire to work well and excel.

The importance of having human resources with good and optimal performance is definitely expected by the staff of the Lantamal V Surabaya Accounting department. However, there are several problems that we have discussed above and occur in the environment of the Lantamal V Surabaya Accounting personnel so that they become obstacles to obtaining high performance. This is indicated by the lack of locus of control, including it is more difficult to adapt to new situations or changes, especially at the time of change of account leadership so that it affects the mindset and intellectual ability is relatively low. It is also reflected in the lack of job satisfaction, despite getting various facilities from the office, it cannot be denied that the income received in the form of salaries and allowances is still far from being feasible in fulfilling the needs of life in a large city like Surabaya. This clearly affects the implementation of work, both analysis and problem solving in the official environment so that it has a strong impact on the organization.

\section{LITERATURE REVIEW AND HYPOTHESIS DEVELOPMENT}

\section{A. Employee Performance}

Performance is the work achieved by a person in accordance with the standards of his work for a certain period. Performance is one of the total collections of work that is within the worker [5]. Performance as a comparison of the results achieved with the participation of labor union time (usually per hour) [6]. The definition of employee performance is an expression such as output, efficiency and effectiveness are often associated with productivity [6]. Performance is a process that refers and is measured over a certain period of time based on the provisions or agreements that have been previously determined [7]. Performance is a work result that can be achieved by a person or group of people in an organization, in accordance with their respective authorities and responsibilities, in an effort to achieve the goals of the organization concerned legally, does not violate the law and does not conflict with morals and ethics [5].

Performance is basically what employees do or don't do [8]. One that is used to measure performance is to look at the dimensions of employee performance. Dimensions and indicators of employee performance are:

1) Quality (Quality) Is the result of hard work from employees in accordance with the objectives set by the company previously. If the results achieved by the employee are high, then the employee's performance is considered good by the company or in accordance with predetermined standards. This means it is a level that shows the work process, or the results achieved for a job approaching perfection.

2) Quantity (Quantity) Is the result of hard work from employees who can reach the maximum scale that has been determined by the company. With the results set by the company, the employee's performance is correct and correct.

3) Timeliness, employees can work in accordance with the working time standards set by the company. By working in accordance with predetermined time standards, the employee's performance is good. With timeliness, which is a level that indicates that a job can be completed faster than the specified time, the employee's performance is good.

4) Attendance, Attendance is something that must be maintained by employees. The presence of employees can be a measure of whether employees like their jobs. Employees with more attendance generally perform better than employees with less attendance.

5) Ability to work together, with employees who have a high sense of self-respect for their work, employees try to achieve the best results in the job. Therefore, with a high sense of self-respect for their work, it is hoped that employees 
can improve their performance at work. The ability to work together which is a level of condition for employees can create a comfortable atmosphere at work, self-confidence, good communication between colleagues so that performance increases are created.

\section{B. Locus of Control}

The concept of locus of control (control center) was first put forward by Rotter in 1966, a social learning theorist. Locus of control is one of the personality variables (personality), which is defined as an individual's belief in his or her own destiny. Individuals who have the belief that fate or events in their life are under their control are said to have an internal locus of control. Meanwhile, individuals who have the belief that the environment has control over fate or events that occur in their life are said to have external locus of control [9].

Whereas the results achieved by internal locus of control are ascribed to his activities [10]. Whereas in the individual, external locus of control assumes that the success achieved is controlled from the surrounding conditions. Rotter's internal external locus of control dimension focuses on the strategy to achieve goals regardless of the origin of those goals. Someone who has an internal locus of control will see the world as something that can be predicted, and individual behavior plays a role in it. Individuals who have an external locus of control will see the world as something that cannot be predicted, as well as in achieving goals so that individual behavior will not have a role in it. There are two dimensions of locus of control that are very prominent from each individual, namely internal and external locus of control. The locus of control dimension has several indicators in each dimension consisting of [11]:

1) Internal locus of control,

a) The belief that the events they experience are the result of their own behavior and actions;

b) Have good control over their own behavior;

c) Tend to be able to influence others;

d) Convinced that his efforts can be successful;

e) Actively seeking information and knowledge related to the situation at hand.

2) External locus of control,

a) Individual belief that other people's power, destiny, and opportunity are the main factors that influence what is experienced;

b) Having poor control over their own behavior;

c) Tend to be influenced by others;

d) Often not sure that his efforts will be successful;

e) Less actively seeking information and knowledge related to the situation at hand.

\section{Job Satisfaction}

Job satisfaction is an affective or emotional response to various aspects or aspects of a person's job so that job satisfaction is not a single concept. A person can be relatively satisfied with one aspect of a job and dissatisfied with one or more other aspects. Job Satisfaction is a worker's (positive) attitude towards his job, which arises based on an assessment of the work situation. The assessment can be carried out on one of the jobs, the assessment is carried out as a sense of appreciation in achieving one of the important values in the work. Satisfied employees prefer their work situation rather than dislike them [6].

Job satisfaction is a pleasant emotional attitude and loves his job. This attitude is reflected by work morale, discipline, and work performance. Employee job satisfaction must be created as well as possible so that employee morale, dedication, love, and discipline can increase. Employees themselves are every person who works by selling their energy (physical and mental) to a company and obtaining compensation for services provided to the company [12]. Job satisfaction can occur within the job, outside of work, and a combination of inside and outside work. There are 5 (five) indicators of job satisfaction, namely [13]:

1) The Work itself. Namely in this case where work provides interesting tasks, opportunities to learn and develop, and opportunities to accept responsibility;

2) Pay (Salary), namely the amount of wages received and the level at which this can be seen as something that is deemed appropriate and reasonable in the company;

3) Promotional Opportunities, namely opportunities to advance or opportunities to get a better position, status and expertise in the company;

4) Supervision (Supervision), namely the ability of supervisors to provide technical direction and behavioral support;

5) Co-Worker (co-worker) That is the level where coworkers are technically smart and are a reliable workforce and can provide social support.

\section{Organizational Citizenship Behavior (OCB)}

Organizational Citizenship Behavior is a choice of behavior that is not part of the formal work obligations of an employee but supports the effective functioning of the organization [1]. OCB is a behavior performed by an employee that exceeds formal work obligations but has a good impact because it supports organizational effectiveness [14].

Organizations will function more effectively if employees contribute more than formal tasks [15]. Employees who work in organizations that have high performance have better OCB, compared to employees who work in organizations that have poor performance. So that when in a company organization an employee has a high OCB, which is able to work extra beyond the job description based on their own desires, it will be easier to help the company function effectively to achieve its goals. The dimensions of OCB are as follows [16]:

1) Altruism, the behavior of helping colleagues who face difficulties that are closely related to the operational tasks of the organization without coercion.

2) Conscientiousness, the behavior shown exceeds the minimum requirements desired by the company, such as being present early, making maximum use of working time

3) Sportsmanship, positive behavior towards the organization, by tolerating or not complaining or demanding less than ideal conditions in the organization.

4) Courtesy, the behavior of maintaining good relations with fellow colleagues, preventing conflicts in order to avoid interpersonal problems

5) Civic Virtue, behavior that reflects taking responsibility and participating in the sustainability of the organization. 


\section{RESEARCH METHODOLOGY}

Based on the description of the literature review above and supported by previous research reviews, Locus of control and Job Satisfaction have no effect on Employee Performance through Organizational Citizenship Behavior (OCB) on staff of the Lantamal V Surabaya Accounting department.

Broadly speaking, the research conducted on the Lantamal V Surabaya Accounting staff will examine and analyze the following:

1) the effect of locus of control (X1) on Organizational Citizenship Behavior / OCB (Z);

2) the effect of job satisfaction (X2) on Organizational Citizenship Behavior / OCB (Z);

3 ) the influence of locus of control (X1) on employee performance (Y);

4) the effect of job satisfaction (X2) on employee performance $(\mathrm{Y})$;

5) the influence of Organizational Citizenship Behavior / OCB (Z) on employee performance (Y). Based on the description above, the framework in this study can be described as follows:

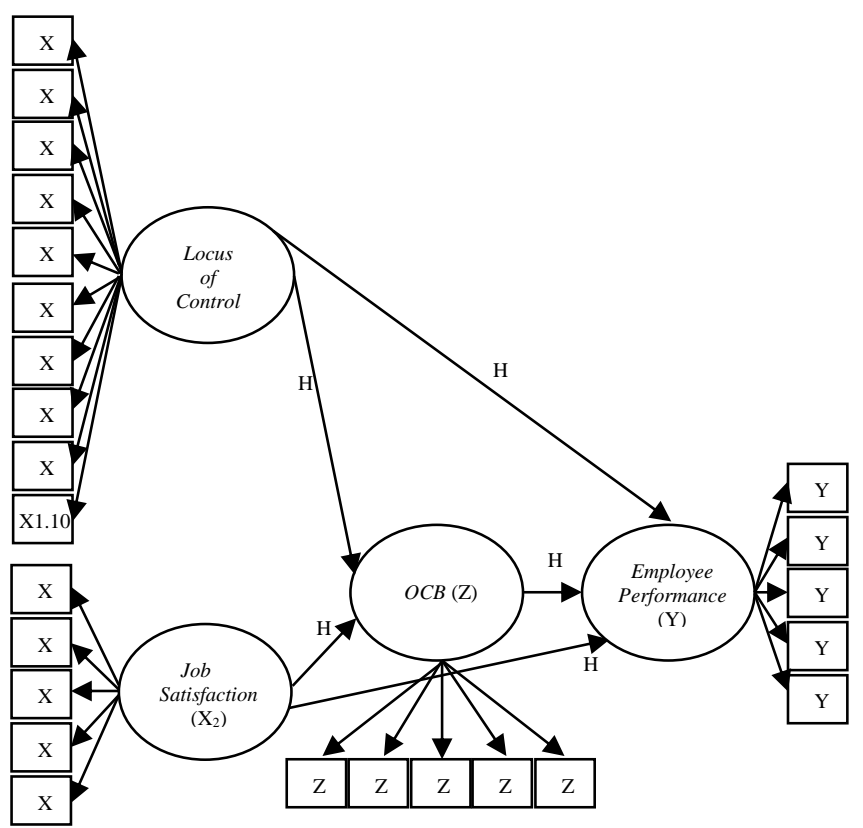

Fig. 1. Framework.

\section{A. Hypothesis}

Based on the research framework, the hypotheses set out in this study are:

a) Locus of control has a significant effect on Organizational Citizenship Behavior (OCB).

b) Job satisfaction has a significant effect on Organizational Citizenship Behavior (OCB).

c) Locus of control has a significant effect on Employee Performance.

d) Job satisfaction has a significant effect against Employee Performance.

e) Organizational Citizenship Behavior (OCB) has a significant effect on Employee Performance.

f) Locus of control has a significant effect on Employee Performance through Organizational Citizenship Behavior (OCB). g) Job satisfaction has a significant effect on Employee Performance through Organizational Citizenship Behavior (OCB).

\section{RESEARCH RESUlT AND DISCUSSION}

In this study, to test the research hypothesis used Partial Least Square (PLS) analysis with the Smart PLS program. Below is a picture of the proposed PLS model.

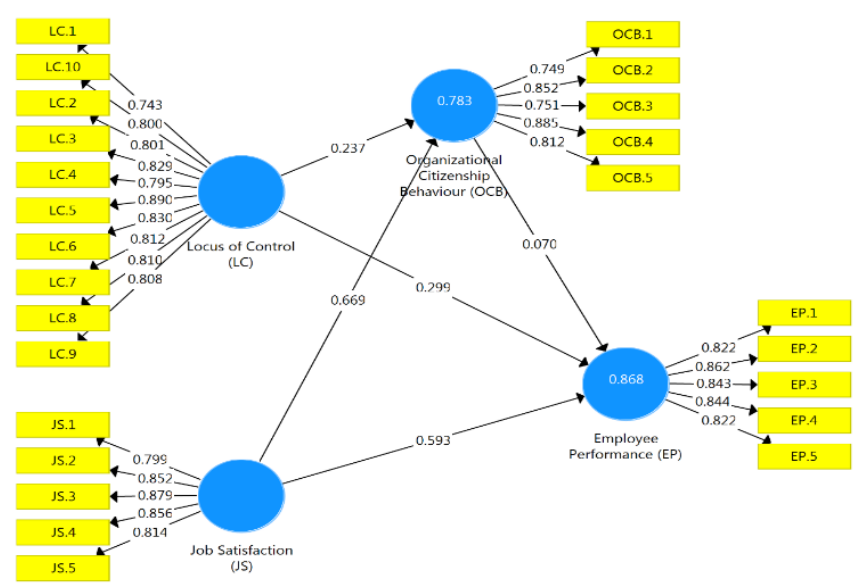

Fig. 2. Research model PLS. Source: appendix 6, processed data.

The results of the inner weight value in Figure 2. above show that the Organizational Citizenship Behavior variable is influenced by Locus of Control and Job satisfaction, while Employee Performance is influenced by Locus of Control, Organizational Citizenship Behavior and Job satisfaction variables which are described in the structural equation below.

$$
\begin{gathered}
\mathrm{OCB}=0.237 \mathrm{LC}+0.669 \mathrm{JS} \\
\mathrm{EP}=0.299 \mathrm{LC}+0.593 \mathrm{JS}+0.070 \mathrm{OCB}
\end{gathered}
$$

\section{A. Hypothesis Test}

\section{Direct Influence of Research Variables}

To answer the research hypothesis the direct effect can be seen in the t-statistic in Table I the following:

TABLE I: HyPOTHESIS TESTING RESULTS (DIRECT EFFECT)

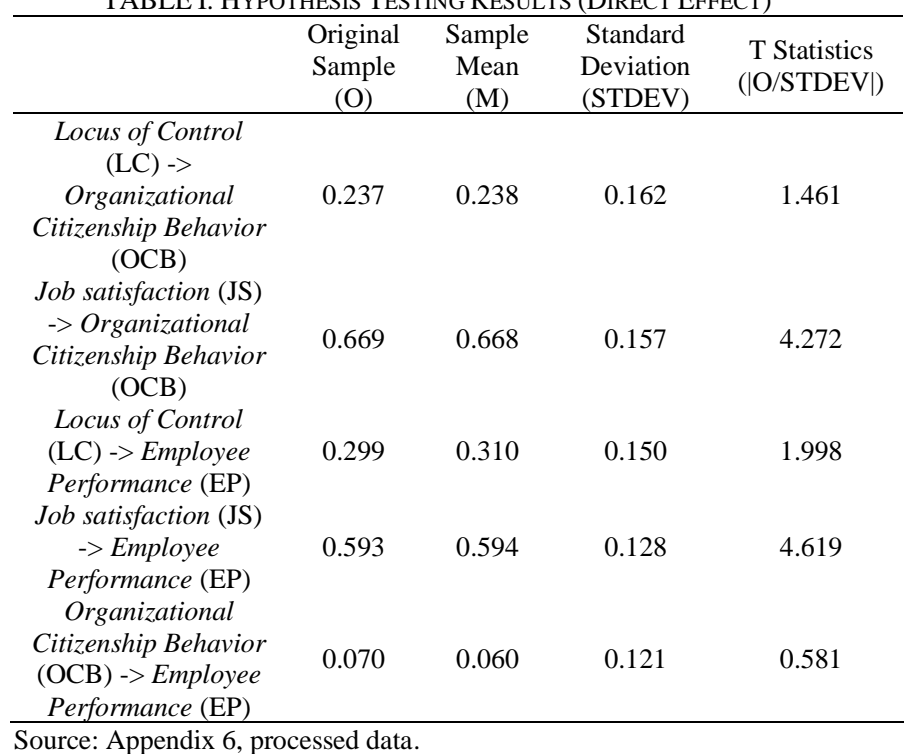


Based on the results of testing the hypothesis, the following results are obtained:

1) Locus of Control has no significant effect on Organizational Citizenship Behavior, because the T statistical value is 1.461 which means it is less than 1.96 .

2) Job satisfaction has a significant effect on Organizational Citizenship Behavior, because the T statistical value is 4.272, which means it is greater than 1.96 .

3) Locus of Control has a significant effect on Employee Performance, because the T statistical value is 1.998 , which means it is greater than 1.96 .

4) Job satisfaction has a significant effect on Employee Performance, because the $\mathrm{T}$ statistical value is 4,619 , which means it is greater than 1.96 .

5) Organizational Citizenship Behavior does not have a significant effect on Employee Performance, because the T statistical value is 0.581 which means it is smaller than 1.96 .

\section{Indirect Influence of Research Variables}

To answer the research hypothesis the indirect effect can be seen in the t-statistic in Table II the following:

TABLE II: HyPOTHESIS TESTING RESUlTS (INDIRECT EFFECT)

\begin{tabular}{|c|c|c|c|c|}
\hline & $\begin{array}{c}\text { Original } \\
\text { Sample } \\
(\mathrm{O})\end{array}$ & $\begin{array}{l}\text { Sample } \\
\text { Mean } \\
\text { (M) }\end{array}$ & $\begin{array}{l}\text { Standard } \\
\text { Deviation } \\
\text { (STDEV) }\end{array}$ & $\begin{array}{c}\text { T Statistics } \\
(|\mathrm{O} / \mathrm{STDEV}|)\end{array}$ \\
\hline $\begin{array}{l}\text { Locus of Control } \\
\text { (LC) -> } \\
\text { Organizational } \\
\text { Citizenship } \\
\text { Behaviour (OCB) - } \\
>\text { Employee } \\
\text { Performance (EP) }\end{array}$ & 0.017 & 0.012 & 0.034 & 0.484 \\
\hline $\begin{array}{c}\text { Job Satisfaction } \\
\text { (JS) -> } \\
\text { Organizational } \\
\text { Citizenship } \\
\text { Behaviour (OCB) - } \\
>\text { Employee } \\
\text { Performance (EP) }\end{array}$ & 0.047 & 0.042 & 0.084 & 0.557 \\
\hline
\end{tabular}

Based on the results of testing the hypothesis, the following results are obtained:

1) Locus of Control does not have a significant effect on Employee Performance through Organizational Citizenship Behavior, because the $\mathrm{T}$ statistical value is 0.484 , which means it is smaller than 1.96. This shows that Organizational Citizenship Behavior is not able to mediate the effect of Locus of Control on Employee Performance.

2) Job Satisfaction does not have a significant effect on Employee Performance through Organizational Citizenship Behavior, because the $\mathrm{T}$ statistical value is 0.557 which means it is smaller than 1.96. This shows that the Organizational Citizenship Behavior is unable to mediate the effect of Job Satisfaction on Employee Performance.

\section{CONCLUSIONS}

Based on the results of the analysis obtained, the following conclusions can be drawn:

1) Locus of Control has no significant effect on Organizational Citizenship Behavior.

2) Job satisfaction has a significant effect on Organizational Citizenship Behavior.
3) Locus of Control has no significant effect on Employee Performance.

4) Job satisfaction has a significant effect on Employee Performance.

5) Organizational Citizenship Behavior has no effect on Employee Performance.

6) Locus of Control does not have a significant influence on Employee Performance through Organizational Citizenship Behavior.

7) Job Satisfaction does not have a significant effect on Employee Performance through Organizational Citizenship Behavior.

In this study, the managerial implications can be stated as follows:

1) The results can be used as material for consideration and evaluation regarding aspects that affect personnel performance (Employee Performance).

2) Although only Jobs Satisfaction has a significant effect on Organization Citizenship Behavior and Employee Performance, Locus of Control has a positive relationship with Employee Performance. Locus of Control as individual personnel's beliefs about their ability to be able to influence their work.

3) Locus of Control can be increased through training and reward activities so as to foster self-confidence in personnel. The locus of control factor is very important in influencing job satisfaction and personnel performance, either directly or indirectly.

4) Jobs Satisfaction has an effect on increasing Employee Performance. Management needs to pay attention to the Jobs Satisfaction felt by personnel both materially and the support provided.

5) Organization Citizenship Behavior affects Employee Performance. This shows that the attitudes contained in the Organization Citizenship Behavior that are owned by personnel need to be developed so that they have a positive impact on individuals, groups and organizations.

In this study there are still limitations, but with this limitation it is hoped that improvements can be made for future research, while the limitations in this study are as follows:

1) Limitations on research that are only carried out in the scope of Accounting personnel at Lantamal V Surabaya. This is the cause of the non-effect of locus of control and job satisfaction through OCB mediation on employee performance. With OCB that does not mediate the relationship between Locus of Control and Job satisfaction with Employee Performance, this shows that there are limitations in the research so that it can become a research gap for future researchers.

2) Because the Lantamal V Surabaya is a large of organization, it is better if a thorough research is carried out.

3) There are still inconsistent answers to the questionnaire according to researchers' observations. Because respondents tend to be less careful with existing statements so that there is inconsistency in answering the questionnaire. 


\section{REFERENCES}

[1] Robbins, S.P. dan T. A. Judge. 2017. Organizational Behaviour, Edisi. 13, Jilid 1. Jakarta: Salemba Empat.

[2] Aruan, Q. S. dan Fakhri, M. 2015. Pengaruh Lingkungan Kerja Terhadap Kepuasan Kerja Karyawan Lapangan Departemen Grasberg Power Distribution PT. Freeport Indonesia. MODUS Vol.27 (2): 141162, 2015.Ayudiati (2010).

[3] Safitri, U. R. 2016. Pengaruh kepemimpinan dan lingkungan kerja terhadap kinerja karyawan melalui kepuasan kerja (Studi kasus pada karyawan Universitas Boyolali). Jurnal Excellent, 6(2), 1-9.

[4] Melati, I. I. 2011. "Faktor-Faktor Yang Mempengaruhi Kinerja Pegawai (Studi Empiris Pada Kementerian Keuangan Kantor Wilayah Jawa Tengah)". Skripsi. Ekonomi Universitas Diponegoro Semarang

[5] Sinambela, Lijan Poltak. 2016. Manajemen Sumber Daya Manusia: Membangun. Tim Kerja yang Solid untuk Meningkatkan Kinerja. Jakarta: Bumi Aksara.

[6] A.A. Anwar Prabu Mangkunegara. (2017). Manajemen Sumber Daya Manusia Perusahaan, Bandung: Remaja Rosdakarya.

[7] Edison, Emron., Y. Anwar., dan I Komariyah. 2016. Manajemen Sumber Daya. Manusia. Bandung: Alfabeta.

[8] Mathis, Robert L., dan John H. Jackson. 2015. Manajemen Sumber Daya Manusia, Edisi 9, Dialihbahasakan oleh Jimmy Sadeli dan Bayu Prawira Hie. Jakarta: Salemba Empat.

[9] Suprayogi, T. T. (2017). "Locus of Control Dan Kinerja Karyawan: Uji Komparasi”. Jurnal Riset Manajemen dan Bisnis (JRMB) Fakultas Ekonomi UNIAT. 2 (2): 131 - 138.

[10] Kreitner, Robert dan Angelo Kinicki. 2016. Perilaku Organisasi. Edisi 9. Buku 1. Jakarta: Salemba Empat.

[11] Fadilah, F., dan S. R. Mahyuny. (2018). "Analisis Faktor Yang Mempengaruhi Locus of Control Mahasiswa Pendidikan Matematika Fkip Universitas Samudra". JIPI (Jurnal IPA dan Pembelajaran IPA). 02 (02): 100-105.

[12] Hasibuan, Malayu S.P. 2016. Manajemen Sumber Daya Manusia. Edisi. Revisi. Jakarta: Penerbit PT Bumi Aksara.

[13] Luthans, F. (2016). Perilaku Organisasi, Alih Bahasa V. A. Yuwono. Yogyakarta: Penerbit Andi Offset.

[14] Robbins, S, P. (2015). Perilaku Organisasi. Jakarta: Salemba Empat.

[15] Amira, C., Lubis, R., dan Hafasnuddin. (2015). "Pengaruh Kepuasan Kerja Karyawan Dan Komitmen Organisasi Terhadap Organizational Citizenship Behavior (OCB) Serta Dampaknya Pada Kinerja Organisasi Pada Pt Lafarge Cement Indonesia (LCI) Aceh Besar". Jurnal Manajemen. Pascasarjana Universitas Syiah Kuala. 4 (1): 201 210.

[16] Organ, D. W. (1998). Organizational Citizenship Behavior: The Good Soldier Syndrome. Lexington, MA: Lexington Books.

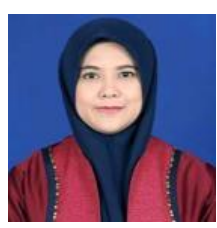

Dyna Tistianingtyas was born in Sidoarjo in September 2, 1980. Graduated with a Bachelor degree of Physics Education at the State University of Surabaya in 2004 and currently studying Human Resource Management for post graduate program at Mercu Buana University.

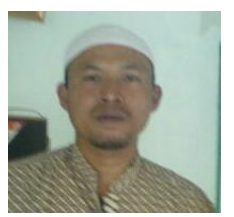

Parwoto was born in Purwokerto, in June 19, 1971. Graduated with a Bachelor degree of Industrial Engineering, graduated with a Master degree of Management, graduated with a Doctoral degree of Management, and currently a Lecturer for Human Resource Management at Mercu Buana University. 